\title{
MECHANISM OF OFFSHORE SAND DISCHARGE INTO SUBMARINE CANYON TRIGGERED BY CONSTRUCTION OF DETACHED BREAKWATERS CLOSE TO SHORELINE
}

\author{
Koji Yamada ${ }^{1}$, Takaaki Uda ${ }^{2}$, Yoshio Suwa' ${ }^{1}$, Toshiro San-nami ${ }^{3}$, \\ Kou Furuike ${ }^{3}$ and Toshinori Ishikawa ${ }^{2}$
}

\begin{abstract}
Several submarine canyons have developed offshore of the Aramata region of the Shimoni-ikawa coast in Toyama Bay, which is one of the three deep bays in Japan. The Kurobe River with a steep bed slope flows into the sea immediately north of this region, and a large amount of sediment has been supplied to this area, which has been transported by southward longshore sand transport. However, beach erosion has occurred owing to the decrease in sediment supply from the Kurobe River. Furthermore, since the construction of detached breakwaters as a measure against beach erosion, offshore sand transport has accelerated and beach erosion has become more severe. In this study, aerial photographs and bathymetric survey data were analyzed, then the mechanism of offshore sand transport was investigated using the BG model proposed by Serizawa et al. (2007).
\end{abstract}

Keywords: submarine canyon; offshore sand transport; detached breakwater; Shimoni-ikawa coast

\section{INTRODUCTION}

Sand loss into a submarine canyon may be one of the important factors in the erosion of a coast where the fluvial sediment supply has been exhausted, because it causes a net loss of sand within a littoral cell. On the Shimoni-ikawa coast, extending along the marginal part of the alluvial fan of the Kurobe River, as shown in Fig. 1, submarine canyons have developed very close to the coastline. This coast has been formed by a large volume of fluvial sediment supplied from the Kurobe River, and the shoreline has advanced for many years. However, sediment supplied from this river has markedly decreased because of the construction of dams in the upstream basin along with riverbed excavation. Also, southward longshore sand transport to the coast has been obstructed by the construction of a fishing port breakwater located upcoast. On the south side of the river mouth, the Aramata region, beach erosion has been severe in recent years because of a lack of sediment supply. Sand supplied from the river passes through this region, but immediately offshore of this region several submarine canyons exist, and part of the sand is considered to be lost into the submarine canyons. Uda et al. (1989), Uda (1997) and Kanazawa et al. (2006) studied the field conditions around these submarine canyons through field observations, but the exact cause of sand loss into the submarine canyons has not yet been clarified, and therefore it is difficult to take concrete measures against beach erosion. In this study, shoreline changes using past aerial photographs and measurement by a narrow multibeam survey were carried out, and the mechanism of sand loss into the submarine canyon was numerically investigated using the BG model (Serizawa et al., 2007).
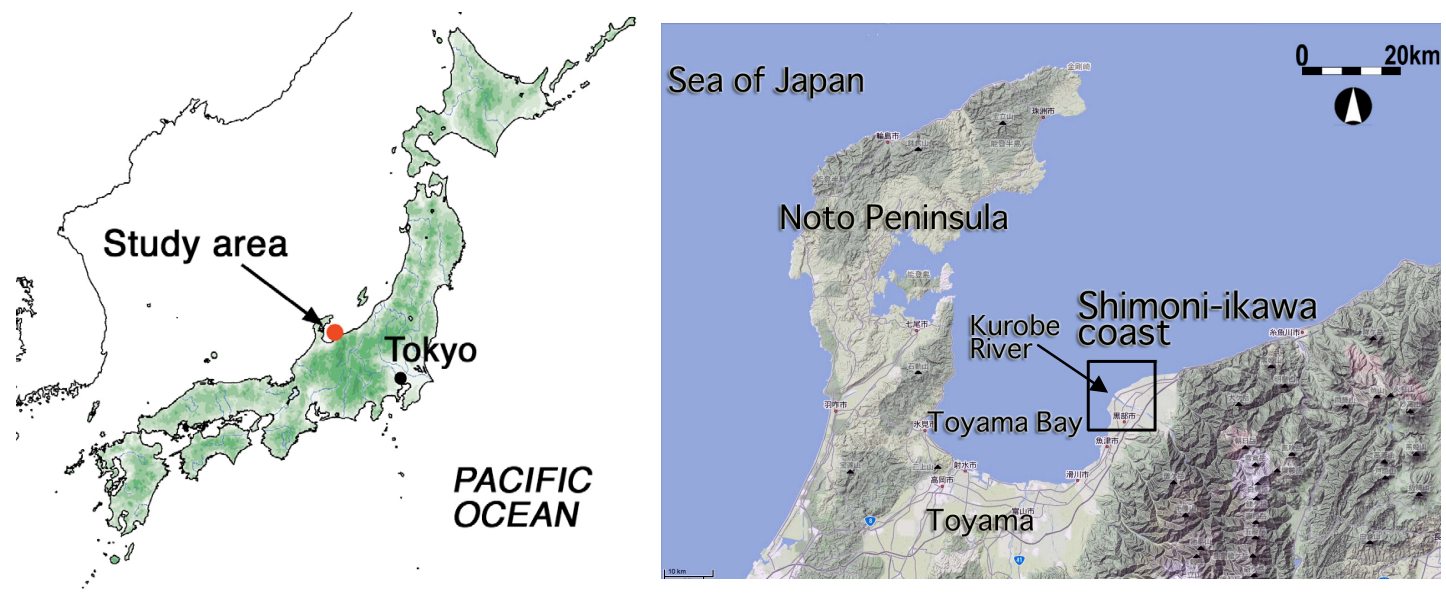

Figure 1. Location of Shimoni-ikawa coast in Toyama Bay.

\footnotetext{
${ }^{1}$ National Institute for Land and Infrastructure Management, 1 Asahi, Tsukuba, Ibaraki 305-0804, Japan

${ }^{2}$ Public Works Research Center, 1-6-4 Taito, Taito, Tokyo 110-0016, Japan

${ }^{3}$ Coastal Engineering Laboratory Co., Ltd., 1-22-301 Wakaba, Shinjuku, Tokyo 160-0011, Japan
} 


\section{FIELD CONDITIONS AROUND SUBMARINE CANYONS}

Figure 2 shows the bathymetry between the Kurobe River mouth and the Aramata region measured in 2005 by a narrow multibeam survey and the alignment of transects. In the black zone extending along the coastline in Fig. 2 no NMB survey data were taken because of the shallowness. Figure 2 shows that six rows of submarine ridges extend offshore of the Kurobe River mouth, and six submarine canyons have developed between transect Nos. 81 and 69. In particular, in the submarine canyon immediately west of transect No. 81, the contour line of $10 \mathrm{~m}$ depth approaches very close to the coastline. In addition, a river mouth terrace, which can often be observed in rivers flowing into the sea with a gentle slope, has not developed because of the very steep slope of 1/5 offshore of the Kurobe River mouth.

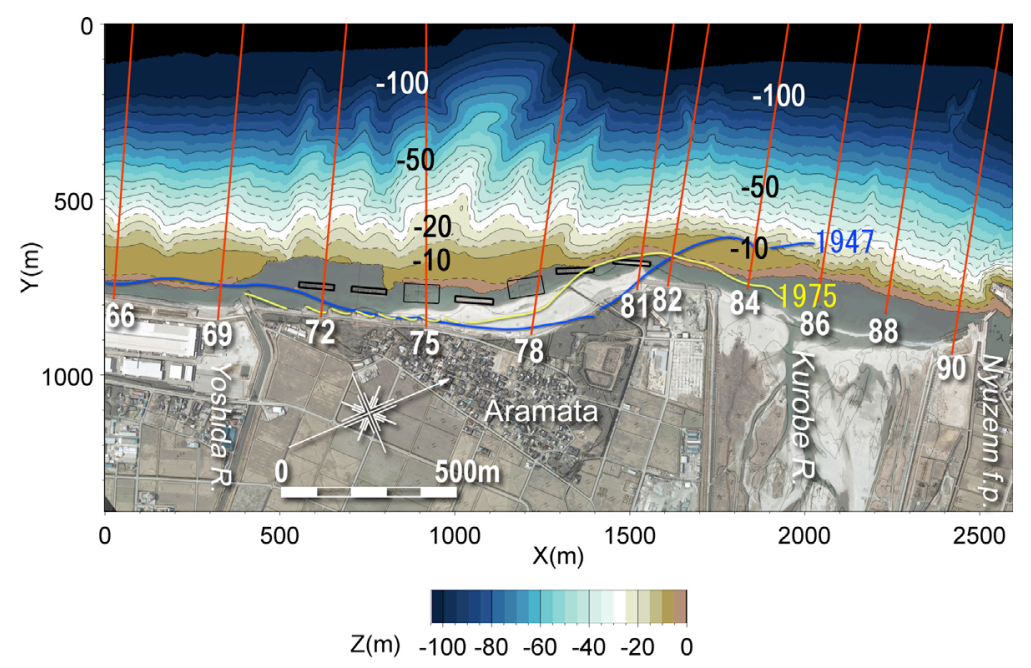

Figure 2. Bathymetry between Kurobe River mouth and Aramata region, and alignment of transects.

A shelf with a gentle slope has developed in the zone shallower than $10 \mathrm{~m}$ depth between transect Nos. 84 and 82, but this shelf narrows at transect No. 82 and disappears at transect No. 81. On the other hand, a shelf with a gentle slope exists between transect Nos. 78 and 75, south of the submarine canyon.

The shoreline configurations in 1947 and 1975 are also shown in Fig. 2. Comparing the shoreline in 1947 and the present shoreline, the shoreline has significantly advanced behind the detached breakwaters and artificial reef in the Aramata region. The location where the offshore steep slope begins coincides with the shoreline position in 1947 at transect No. 84, and a gentle slope has developed landward of this point, suggesting that this gentle slope was formed as a result of erosion. However, near transect No. 86, the shoreline in 1947 is located offshore of this point. In this case, when sand is transported away by southward longshore sand transport, a gentle slope should be formed by erosion in the erosion zone, but no gentle slope has formed. This suggests that submarine landslide may have occurred causing offshore sand loss near the location where the shoreline protruded in 1947. Between 1947 and 1975 , the shoreline rotated clockwise by $42^{\circ}$ with a nodal point at No. 82, because the shoreline at the river mouth receded.

In the Aramata region, where the shoreline has significantly advanced compared with its position in 1947 owing to the construction of detached breakwaters, the region between the $10 \mathrm{~m}$ depth contour and the shoreline has become extremely narrow, suggesting that part of the sand transported in the longshore direction have been transported away through the submarine canyon.

\section{ANALYSIS OF SHORELINE CHANGES USING AERIAL PHOTOGRAPHS}

The shoreline changes along a $2.6 \mathrm{~km}$ stretch of shoreline including the Kurobe River mouth and Aramata region were investigated using aerial photographs. Figure 3 shows the sequence of shoreline changes of this area between 1947 and 2008 as well as the shoreline configuration in 1947 and the alignment of bathymetric surveys. In 1947, the shoreline in front of the Kurobe River mouth protruded markedly, and the shoreline curvature changed from convex to concave near transect No. 81, forming a continuous foreshore in the entire zone. By 1975, the shoreline at the Kurobe River mouth had significantly receded and the shoreline had rotated clockwise by about $25^{\circ}$ with a nodal point located at transect No. 82. Simultaneously, the shoreline immediately south of transect No. 82 markedly 

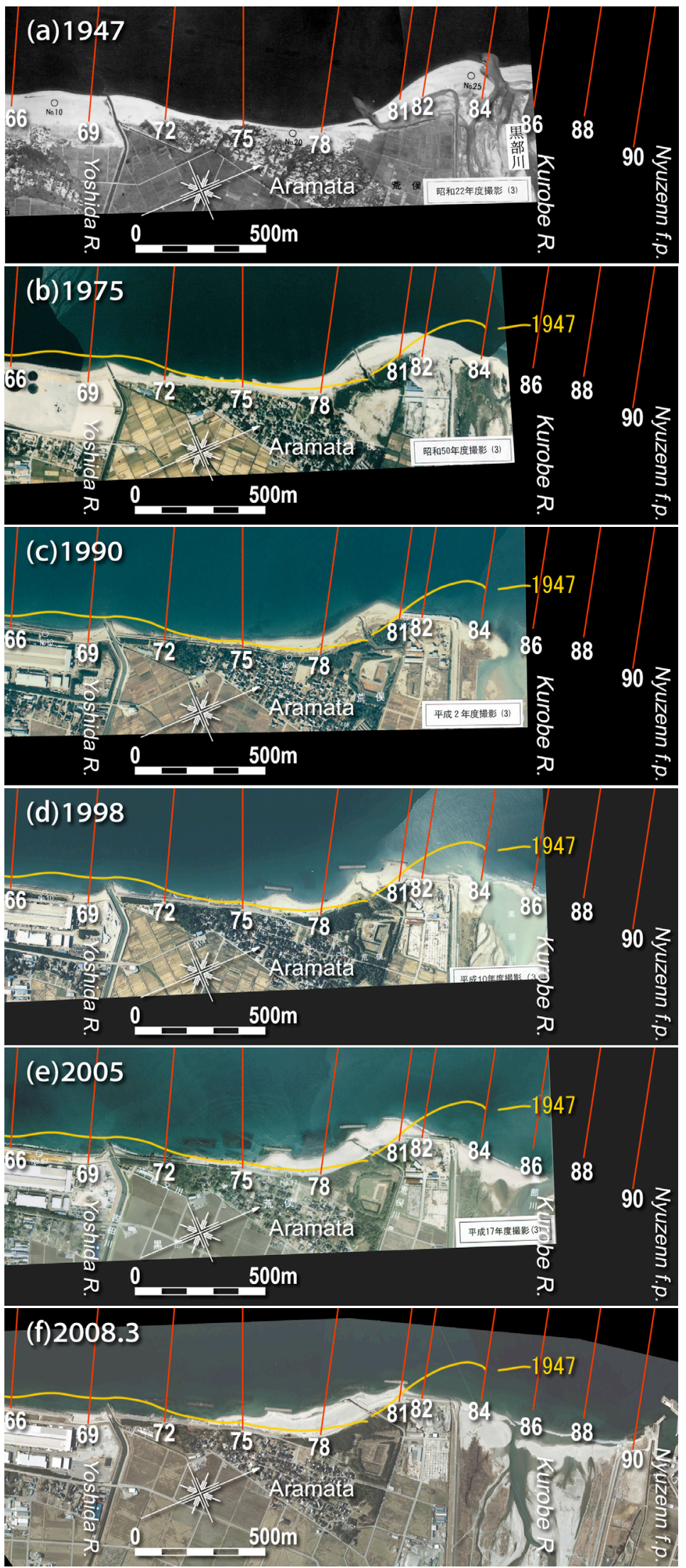

Figure 3. Shoreline changes between 1947 and 2008. 
advanced, forming a shoreline with an arc shape. Furthermore, beach erosion occurred downcoast of the Yoshida River mouth, and many short groins were constructed in the southern part of the Aramata region. The shoreline changes between 1947 and 1975 suggest that the predominant wave direction at the Kurobe River mouth was approximately from $\mathrm{N} 40^{\circ} \mathrm{W}$, normal to the mean shoreline in 1975 at the river mouth. Under the condition of this oblique wave incidence, it is considered that strong southward longshore sand transport could be generated at all locations in the study area in 1947.

By 1990, the seawall on the left bank of the Kurobe River mouth had become directly exposed to waves over a length of $200 \mathrm{~m}$. As a result, the left river mouth bar was isolated in the river channel and moved into the river mouth. By 1998, detached breakwater Nos. 1, 2 and 3 had been constructed in the southern part of the river mouth with the development of a tombolo behind detached breakwater Nos. 2 and 3. Because the shoreward zone of detached breakwater No. 1 had become completely filled with sand by 1995, the sand necessary for the formation of tombolos behind detached breakwater Nos. 2 and 3 is assumed to have been transported southward through the offshore zone of detached breakwater No. 1. Note that the detached breakwaters were constructed very close to the submarine canyons, showing that their construction is the key factor determining sand movement. By 2005, the shoreline north of detached breakwater No. 1 had markedly receded while maintaining an oblique shoreline, the normal direction to which was $\mathrm{N} 44^{\circ} \mathrm{W}$. By 2008 , the shoreline near detached breakwater No. 1 had receded, and the detached breakwater had become isolated with a small tombolo behind the breakwater. Furthermore, sand was deposited around the artificial reef constructed between detached breakwater Nos. 2 and 3, and an almost straight shoreline was formed.

\section{CHANGE IN LONGITUDINAL PROFILES}

The longitudinal profile along transect No. 69 immediately south of the Yoshida River mouth is shown in Fig. 4(a). Along this profile, although a seabed with a slope of $1 / 20$ extends between the shoreline and a depth of $10 \mathrm{~m}$, the profile has a break at a depth of $10 \mathrm{~m}$, and a steep slope of $1 / 4.7$ exists in the zone deeper than $10 \mathrm{~m}$. Taking into account the fact that along this transect, the shoreline receded by 70 m between 1947 and 2008 due to erosion, as shown in Fig. 3, the relatively gentle slope in the zone shallower than $10 \mathrm{~m}$ is considered to be mainly formed by this erosion, and the depth of closure is approximately $10 \mathrm{~m}$.

Along transect No. 78, crossing artificial reef No. 1 with a crown depth of $2 \mathrm{~m}$, the shoreline advanced by $85 \mathrm{~m}$ between 1947 and 2009, as shown in Fig. 3. The shoreline also advanced shoreward of the artificial reef according to the profile changes, as shown in Fig. 4(b), whereas the location of 10 $\mathrm{m}$ depth advanced by $16 \mathrm{~m}$ between 1987 and 2005 in the offshore zone of the reef, and the seabed slope between 10 and $20 \mathrm{~m}$ depth steepened, reaching a slope of 1/3.6 in 2005. On the other hand, the seabed slope in the zone shallower than $10 \mathrm{~m}$ depth along this transect is approximately $1 / 18$, almost equal to the slope of $1 / 20$ obtained along transect No. 69. This means that part of the sand was transported from the gently sloping bed toward the offshore zone deeper than the depth of closure when it was transported southward on the sloping bed between $5.6 \mathrm{~m}$ depth, offshore of the artificial reef, and the depth of closure of approximately $10 \mathrm{~m}$.

The longitudinal profile along transect No. 81 across the detached breakwater is shown in Fig. 4(c). A slope of $1 / 12$ extends from the shoreline to a depth of $6 \mathrm{~m}$, and then the seabed slope steepens: the mean slope between $10 \mathrm{~m}$ and $20 \mathrm{~m}$ depth was $1 / 2.4$ in 1987 and $1 / 3$ in 1999. Although the offshore slope gradually became gentle between 1987 and 1999 as a result of erosion, the slope increased from 1999 to 2005 . Even though the depth of closure is $10 \mathrm{~m}$ on this coast, sand was deposited up to a depth of $40 \mathrm{~m}$. Once sand is deposited in the zone offshore of the depth of closure, it is difficult to move by wave action. This strongly indicates that landslides occurred on the seabed because the seabed slope had become excessively steep, reducing its stability (Kanazawa et al., 2006). Furthermore, although the shoreline markedly protruded between transect Nos. 81 and 78 in 1975, as shown in Fig. 3(b), the location where the shoreline protruded further offshore coincides with the location of the head of the submarine canyon, implying that an extremely steep slope had been formed from the shoreline to the deep sea around this area. When southward longshore sand transport occurs on this steep slope, part of the littoral sand is considered to be transported away toward the deep sea because of the instability of the slope due to its steepness.

Assuming the seabed slope determined from the longitudinal profile in 1999 to be approximately in limiting equilibrium, sand deposited on the slope may cause the slope to become unstable, resulting in a landslide, but such a critical steep slope may be restored by the further deposition of sand.

Along transect No. 84 through the river mouth, a convex profile had formed by 1987, but since then the beach profile has markedly eroded up to a depth of $25 \mathrm{~m}$ (Fig. 4(d)). The fact that the profile 

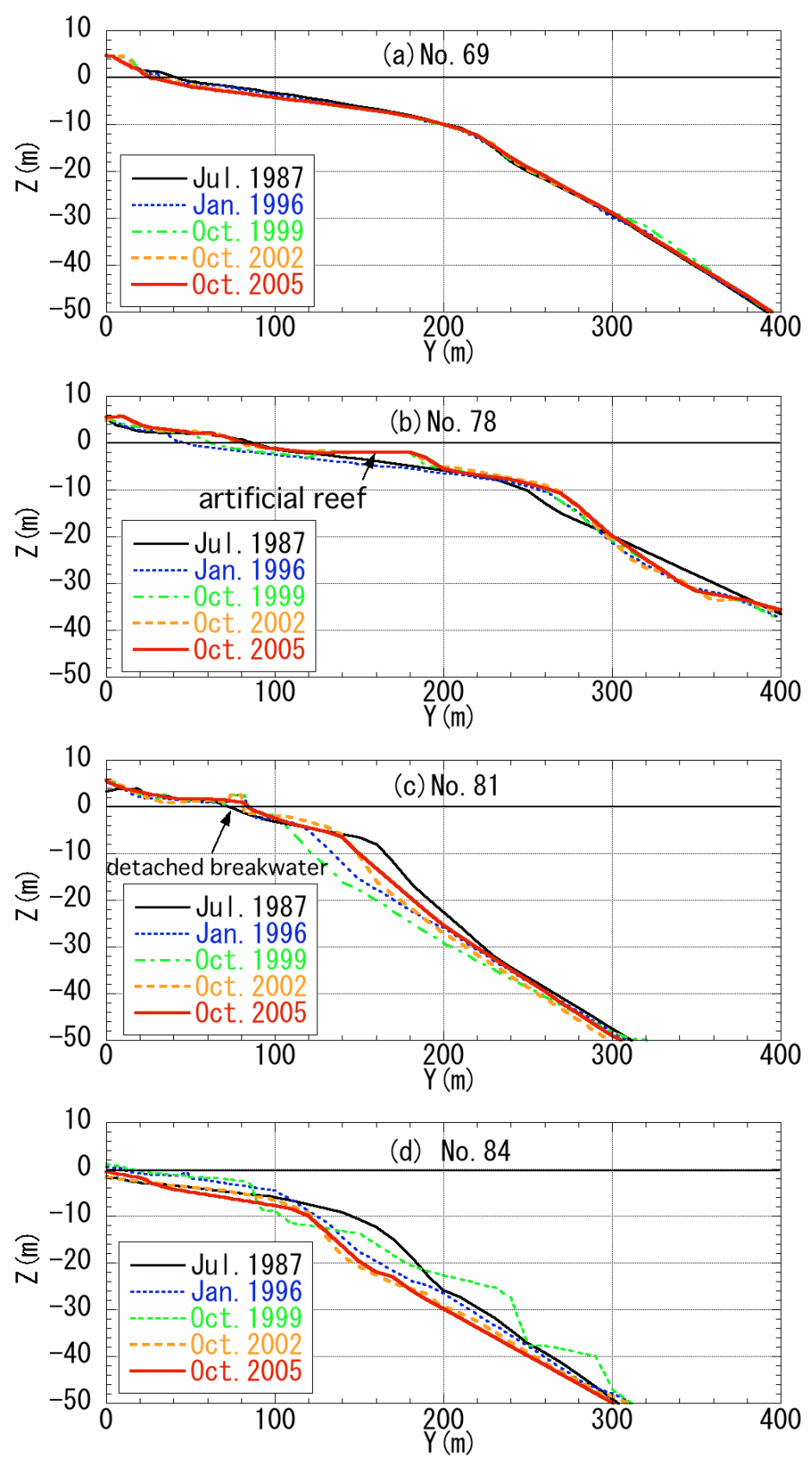

Figure 4. Changes in longitudinal profiles along transect Nos. 69, 78, 81 and 84.

changes occurred at depths greater than the depth of closure of $10 \mathrm{~m}$ on this coast and that the seabed slope at transect No. 84 is as steep as that along transect No. 81 suggest the occurrence of landslides offshore of the river mouth.

Figure 5 shows the detailed bathymetry of the submarine canyon that has developed in the vicinity of transect No. 81. At the west end of detached breakwater No. 1 the width of the seabed with a gentle slope in the zone shallower than $10 \mathrm{~m}$ depth is only $30 \mathrm{~m}$. Although the original shoreline had a concave shape that has been maintained by the shape of the seawall extending along the present coastline, detached breakwater No. 1 was constructed to intersect obliquely with the seawall line, resulting in the proximity of its west end to the submarine canyon. This installation of the oblique detached breakwater is considered to have caused the offshore discharge of sand through the submarine canyon because of the obstruction of southward longshore sand transport. This phenomenon was reproduced using the BG model proposed by Serizawa et al. (2007). 


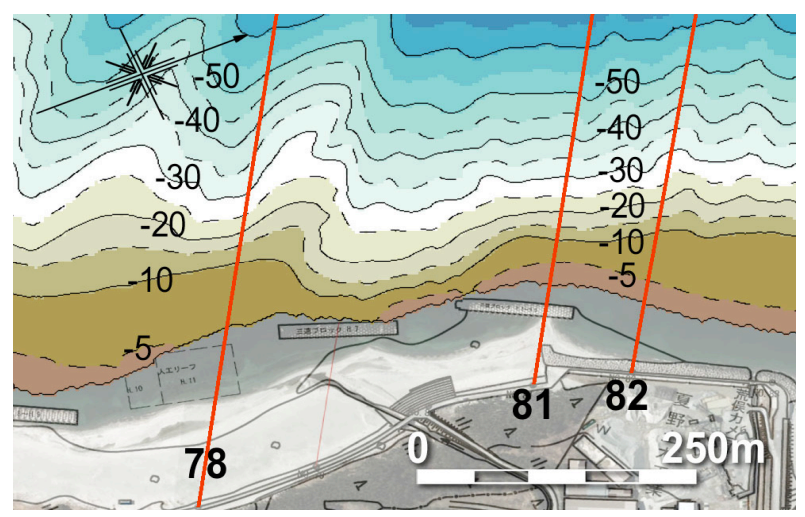

Figure 5. Enlarged bathymetry around submarine canyon immediately south of transect No. 81.

\section{MODEL}

Assume that the sand transport due to waves $\overrightarrow{q_{w}}$ is defined by Eq. (1) (Serizawa et al., 2007). Consider Cartesian coordinates $(x, y)$ and that the elevation at a point $Z(x, y, t)$ is a variable to be solved. Assume that waves are obliquely incident on a coast with a uniform slope of $\tan \beta$. Then, the net sand transport flux due to waves is written as

$$
\overrightarrow{q_{w}}=\frac{G_{w}}{\tan \beta_{\mathrm{c}}}\left[\tan \beta_{\mathrm{c}} \boldsymbol{e}_{w}-\nabla Z\right]
$$

Here, $\overrightarrow{e_{w}}=\left(\cos \theta_{w}, \sin \theta_{w}\right)$ is the unit vector in the wave direction $\theta_{w}, \nabla Z=(\partial Z / \partial x, \partial Z / \partial y)$ is the gradient vector of $Z$, the direction and magnitude of which give the shoreward normal to the contour line and $\tan \beta$, respectively. $\tan \beta_{c}$ is the equilibrium slope resulting in zero net on-offshore sand transport when waves are incident from the direction normal to the shoreline. The coastal domain is discretized using 2-D elements with widths $\Delta x$ and $\Delta y$. The explicit finite-difference method is used to solve the equations.

\section{CALCULATION CONDITIONS}

For the initial bathymetry, the bathymetry measured in 1995 was used, as shown in Fig. 6. Setting a calculation domain $500 \mathrm{~m}$ wide for a stretch of $1500 \mathrm{~m}$ alongshore in the Aramata region, the difference in sand loss into the submarine canyon under the condition with/without detached breakwaters was investigated. Calculation for four cases were carried out: the present bathymetry was reproduced in case 1, the detached breakwaters were installed in case 2,detached breakwaters with an increased wave transmission coefficient were installed in case 3 and detached breakwater No. 1 next to

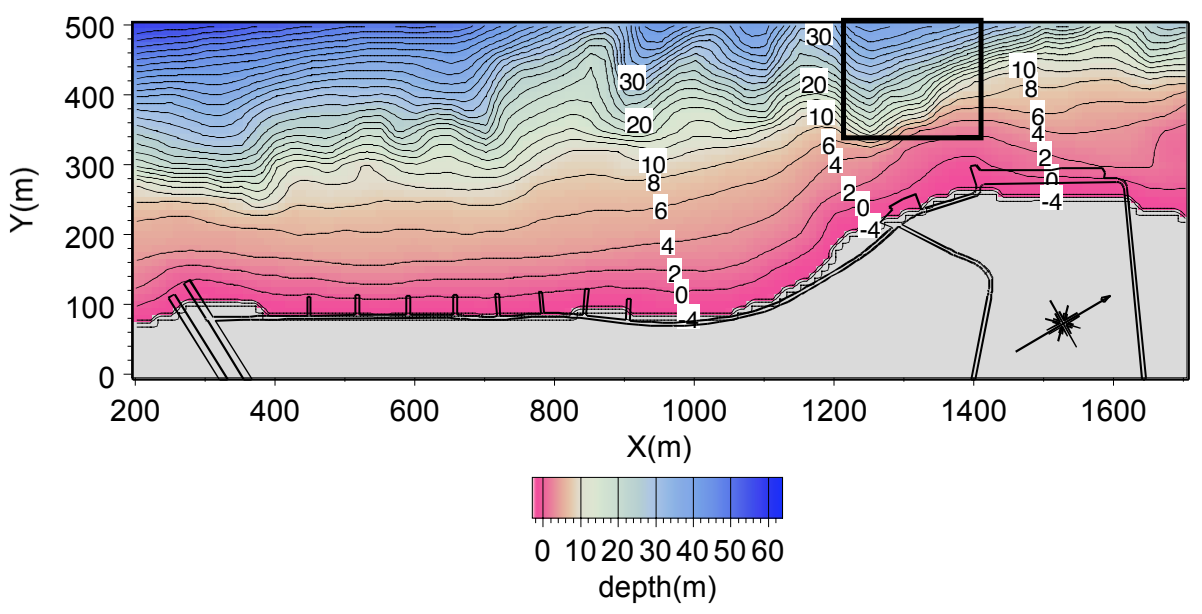

Figure 6. Initial bathymetry used for calculation. 


\begin{tabular}{|c|c|}
\hline Calculation method & $\begin{array}{l}\text { BG model considering grain size change (Serizawa et al., 2007) } \\
\text { Angular spreading method for irregular waves (Sakai et al., 2006) }\end{array}$ \\
\hline Initial bathymetry & Bathymetry measured in 1995 \\
\hline Cases & $\begin{array}{l}\text { Case 1: without detached breakwaters } \\
\text { Case 2: with detached breakwaters } \\
\text { Case 3: increasing transmission coefficient of detached breakwaters } \\
\text { Case 4: removal of detached breakwater No. } 1\end{array}$ \\
\hline $\begin{array}{l}\text { Incident wave } \\
\text { conditions }\end{array}$ & $\begin{array}{l}\text { Energy-mean waves: wave height } H=1.6 \mathrm{~m} \text {, wave period } T=7.2 \mathrm{~s} \text { and wave } \\
\text { direction of } \mathrm{N} 15^{\circ} \mathrm{W}\end{array}$ \\
\hline Sea water level & M.S.L. $\pm 0.0 \mathrm{~m}$ \\
\hline Mesh size & $\Delta x=\Delta y=10 \mathrm{~m}$ \\
\hline Time interval $\Delta t$ & $\Delta t=2 \mathrm{hrs}$ \\
\hline Calculation period & $5 \mathrm{yrs}$ \\
\hline Grain size & $\begin{array}{l}\text { Equilibrium slope and content } \\
\text { Fine-size material }\left(d_{50}=0.3 \mathrm{~mm}\right) \quad \tan \beta=1 / 15 \text { and } \mu_{1}=0.0 \\
\text { Medium-size material }\left(d_{50}=0.7 \mathrm{~mm}\right) \quad \tan \beta=1 / 8 \text { and } \mu_{2}=0.0 \\
\text { (Initial contents in exchange layer was set empty assuming initial bathymetry to } \\
\left.\text { be a solid bed: } \mu_{1}=0.0 \text { and } \mu_{2}=0.0\right) \\
\text { Thickness of exchange layer } 10 \mathrm{~m}\end{array}$ \\
\hline $\begin{array}{l}\text { Depth distribution of } \\
\text { sediment transport }\end{array}$ & Cubic equation given by Uda and Kawano (1996) \\
\hline Depth of closure & $h_{c}=9 \mathrm{~m}$ \\
\hline Berm height & $h_{R}=3 \mathrm{~m}$ \\
\hline $\begin{array}{l}\text { Coefficient of } \\
\text { sediment transport }\end{array}$ & $\begin{array}{l}K_{y}=A / \sqrt{d_{50}}, A=0.02, K_{y}=0.3651 \text { (fine-size material) and } K_{y}=0.2390 \text { (medium-size } \\
\text { material } \\
\text { Ratio of coefficient of cross-shore sand transport to } K_{y} \quad K_{x} / K_{y}=1.0 \\
\text { Coefficient by Ozasa and Brampton (1980) } K_{2}=1.62 K_{x}(\tan \beta=1 / 30) \\
\text { Critical slope } 1 / 2 \text { on land and } 1 / 4 \text { on seabed }\end{array}$ \\
\hline $\begin{array}{l}\text { Boundary } \\
\text { conditions }\end{array}$ & $\begin{array}{l}\text { Sediment supply from Kurobe River } 1.0 \times 10^{5} \mathrm{~m}^{3} / \mathrm{yr} \\
\text { Grain size composition } \mu_{1}=0.33 \text { and } \mu_{2}=0.67 \\
\text { (Source area }: x=1640-1700 \mathrm{~m} \text { and } y=320-410 \mathrm{~m} \text { ) } \\
q_{x}=0 \text { at landward and offshore boundaries } \\
q_{y}=0 \text { at right and left boundaries }\end{array}$ \\
\hline $\begin{array}{l}\text { Wave transmission } \\
\text { coefficient of } \\
\text { coastal structures }\end{array}$ & $\begin{array}{l}\text { Groin } K_{t}=0.0 \\
\text { Detached breakwater } K_{t}=0.4\left(\text { in case } 3 K_{t}=0.8\right) \\
\text { Artificial reef } K_{t}=0.7\end{array}$ \\
\hline
\end{tabular}

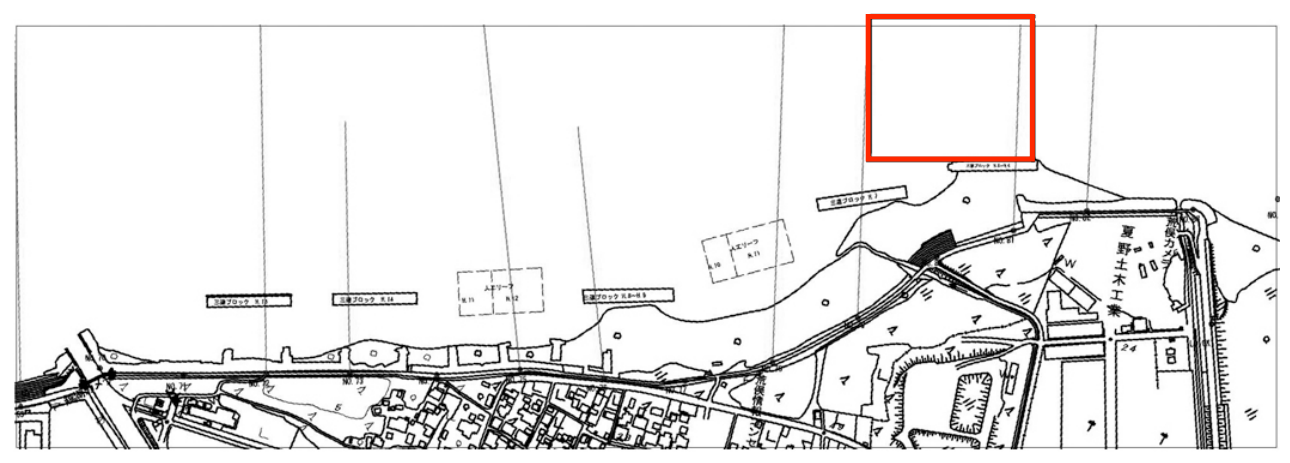

Figure 7. Arrangement of detached breakwaters and artificial reefs. 
the river mouth was removed in case 4 . On the basis of the bathymetric survey data, the depth of closure and berm height were set as $h_{c}=9 \mathrm{~m}$ and $h_{R}=3 \mathrm{~m}$, respectively. The seabed topography measured in 1995 was assumed to be a solid bed, and sediment was supplied from the right boundary, which coincides with the Kurobe River mouth.

For the wave conditions, waves with an energy-mean wave height of $1.6 \mathrm{~m}$ and a wave period of $7.2 \mathrm{~s}$ were assumed on the basis of the observation data obtained at Tanaka observatory offshore of the coast. The incident wave direction of $\mathrm{N} 15^{\circ} \mathrm{W}$ was assumed, which makes an angle of $45^{\circ}$ relative to the straight shoreline between the Kurobe River mouth and Ikuji-bana sand spit. Sediment supply for each grain size, $d_{50}=0.3 \mathrm{~mm}\left(\tan \beta_{c}=1 / 15\right)$ and $d_{50}=0.7 \mathrm{~mm}\left(\tan \beta_{c}=1 / 8\right)$, is assumed to be $3.3 \times 10^{4} \mathrm{~m}^{3} / \mathrm{yr}$ and $6.7 \times 10^{4} \mathrm{~m}^{3} / \mathrm{yr}$, respectively, referring to the results predicted by Uda et al. (1989). Table 1 shows the calculation conditions. Figure 7 show the arrangement of coastal structures.

\section{RESULTS}

Figure 8 shows the predicted results for sand transport flux after five years of wave action with/without detached breakwaters. In case 1, without the detached breakwaters, smooth longshore sand transport occurs alongshore, although there are some disturbances in the groin field. When detached breakwaters were constructed, as in case 2, longshore sand transport was obstructed by
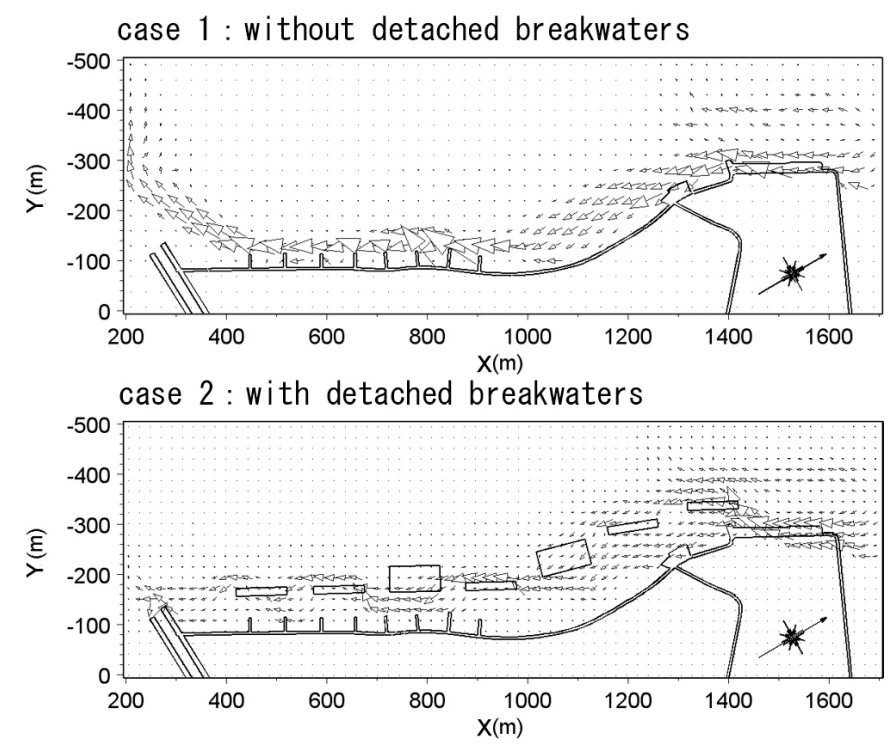

case 3 : increasing transmission coefficient
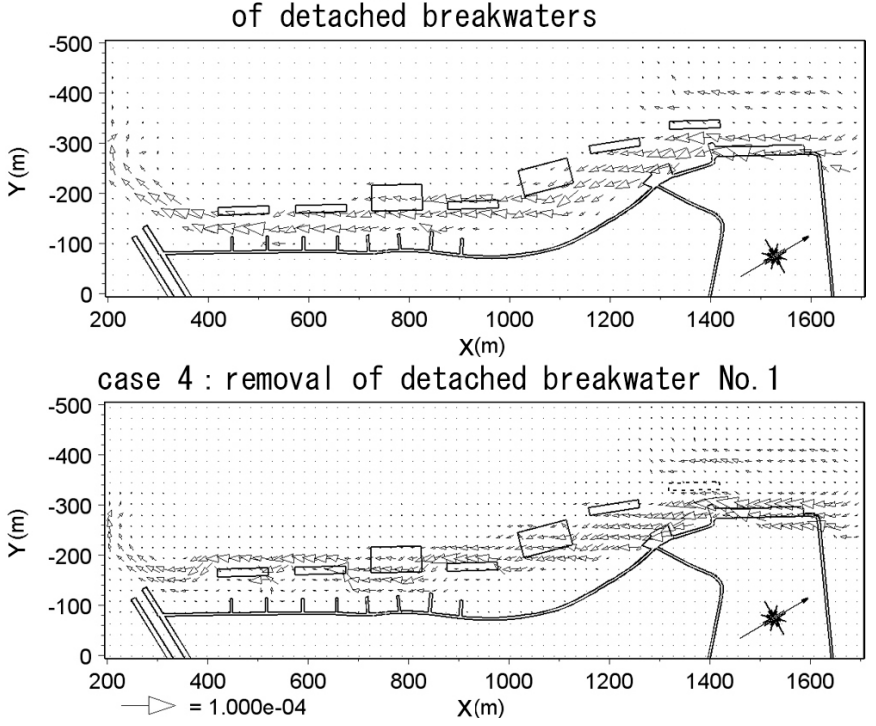

Figure 8. Sand transport fluxes in cases 1-4. 
detached breakwater No. 1 next to the river mouth, inducing the offshore and oblique discharge of sand. This offshore sand transport causes the loss of sand into the submarine canyon. In case 3 , in which the transmission coefficient of the detached breakwaters was increased to 0.8 , longshore sand transport increases. Furthermore, in case 4, in which detached breakwater No. 1 was removed, the amount of sand discharged obliquely was markedly reduced, enabling an increase in longshore sand transport.

Figure 9 shows the calculated bathymetric changes five years after the initial bathymetry in each case. In case 1, the sand loss into the submarine canyon offshore of the Aramata region increased over time. In case 2, in which detached breakwaters were installed, the detached breakwaters obstructed part of the southward longshore sand transport, resulting in the deposition of sand behind the detached breakwaters, and sand loss offshore of detached breakwater No. 1 simultaneously increased. In case 3 , in which the transmission coefficient of detached breakwaters was increased, the sand loss into the submarine canyon was reduced, and southward longshore sand transport also recovered. In case 4, in
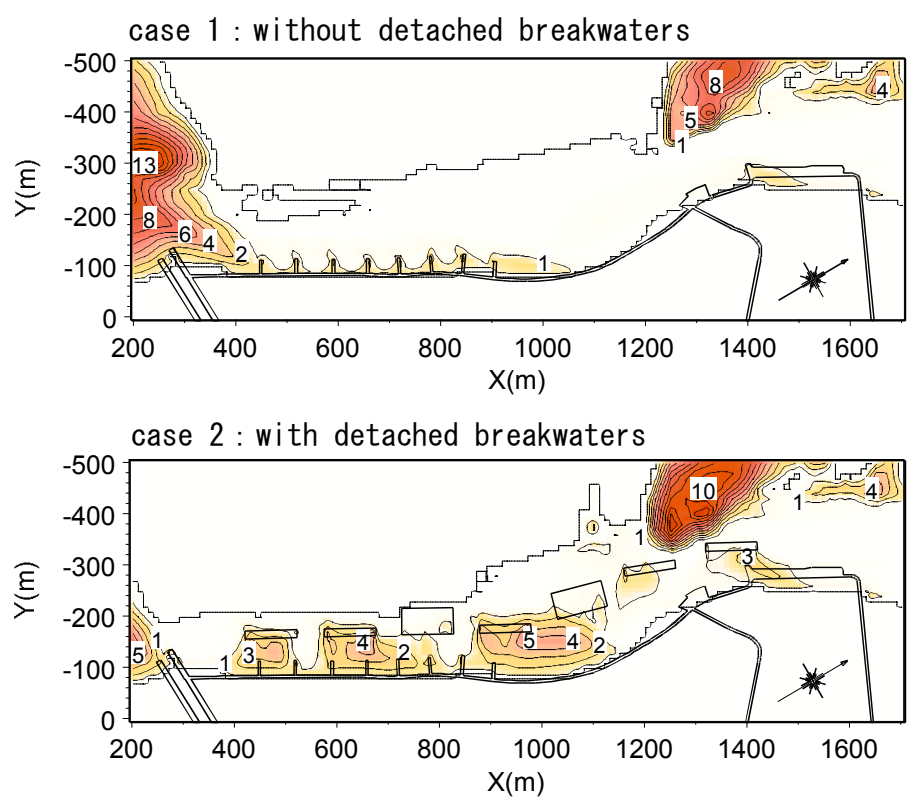

case 3 : increasing transmission coefficient

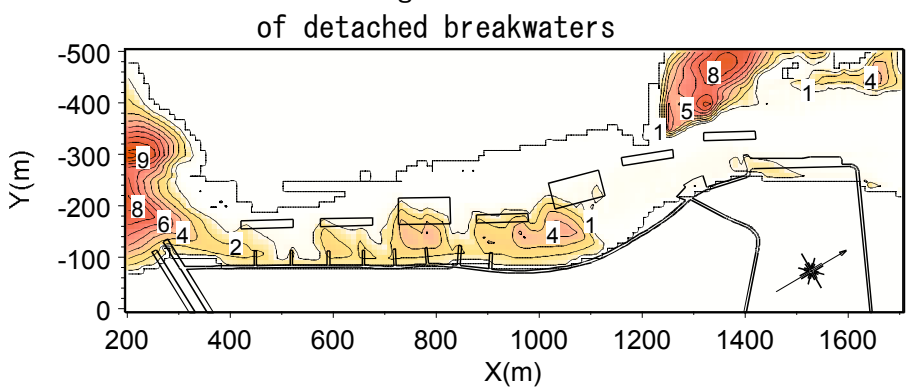

case 4 : removal of detached breakwater No. 1

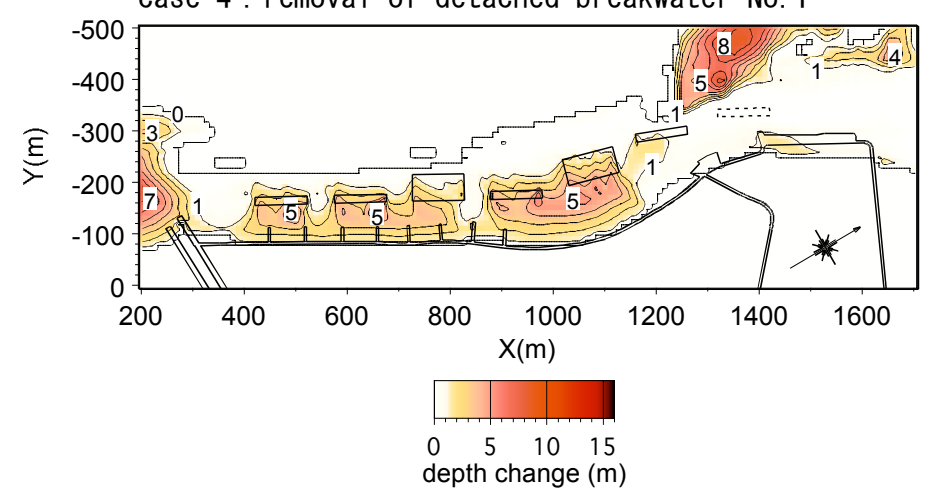

Figure 9. Changes in depth in each case after 5 years. 


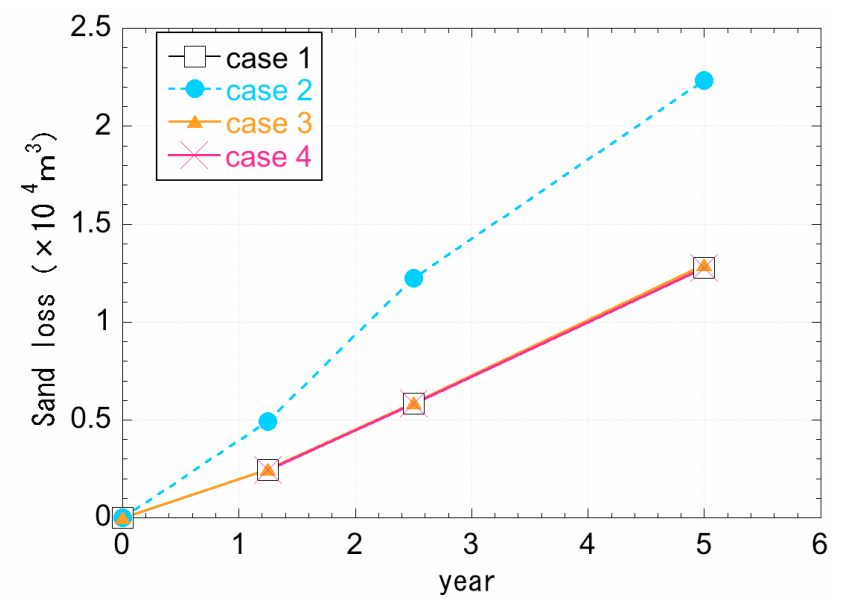

Figure 10. Sand volume lost into submarine canyon over five years.

which detached breakwater No. 1 was removed, the sand loss into the submarine canyon offshore of detached breakwater No. 1 was markedly reduced.

Setting a rectangular calculation domain offshore of the detached breakwaters, as shown in Figs. 6 and 7 , the loss of sand into the submarine canyon in each case was calculated and the change in sand loss with time is shown in Fig. 10. Comparing cases 1, 3 and 4 with case 2 with detached breakwaters, the loss of sand in cases 1,3 and 4 was markedly reduced by $43 \%$ over five years. The fact that the same result was obtained in the cases with no detached breakwaters, the increased transmission coefficient of the detached breakwaters and the removal of detached breakwater No. 1 suggests that the main cause of offshore sand loss into the submarine canyon is the presence of detached breakwater No. 1. Finally, it is concluded that the loss of sand into the submarine canyon can be reduced to an acceptable level by the removal of detached breakwater No. 1.

\section{CONCLUSIONS}

1. On the basis of narrow multibeam survey data, the detailed topography of submarine canyons was studied along with the analysis of bathymetric survey data. Shoreline changes around the submarine canyons were also investigated.

2. The BG model proposed by Serizawa et al. was applied to the prediction of beach changes around the submarine canyon offshore of the Aramata region of the Shimoni-ikawa coast under the conditions that the seabed topography measured in 1995 is assumed to be a solid bed and that sediment is supplied from the right boundary, which coincides with the Kurobe River mouth.

3. It was found that the construction of the detached breakwaters very close to the submarine canyon offshore of the Aramata region blocked southward longshore sand transport, pushing the littoral zone offshore and resulting in accelerated sand loss into the submarine canyon.

4. Because of the same results were also confirmed from the field data, the removal of detached breakwater No. 1 is concluded to be effective for reducing sand loss into the submarine canyon rather than the construction of new structures protruding offshore from the shoreline. Increasing transmission coefficient of detached breakwaters is also effective.

5. The construction of detached breakwaters as a measure against beach erosion may accelerate beach erosion on a coast with submarine canyons.

\section{REFERENCES}

Kanazawa, Y., N. Sasakura, S. Nakayama, M. Fukuhama, K. Yamamoto, S. Hashimoto and S. Henmi. 2006. Large-scale landslides offshore of Kurobe River mouth, Annual Jour. Coastal Eng., Vol. 3, 611-615. (in Japanese)

Ozasa, H. and A. H. Brampton. 1980. Model for predicting the shoreline evolution of beaches backed by seawalls, Coastal Eng., Vol. 4, 47-64.

Sakai, K., T. Uda, M. Serizawa, T. Kumada and Y. Kanda. 2006. Model for predicting threedimensional sea bottom topography of statically stable beach, Proc. 30th ICCE, 3184-3196. 
Serizawa, M., T. Uda, T. San-nami, K. Furuike, T. Ishikawa and T. Kumada. 2007. Model for predicting beach changes on coast with sand of mixed grain size based on Bagnold's concept, Coastal Sediments '07, 314-326.

Uda, T., N. Nakata and A. Omata. 1989. Sand discharge into deep sea offshore of Shimoni-ikawa coast, Annual Jour. Coastal Eng., Vol. 36, 374-378. (in Japanese)

Uda, T. and S. Kawano. 1996. Development of a predictive model of contour line change due to waves. Proc. of JSCE, No. 539/II-35. 121-139. (in Japanese)

Uda, T. 1997. Beach erosion in Japan, Sankaido Press, Tokyo, p. 443. (in Japanese) 